\title{
Editorial
}

\section{Historia@60: Reflection and renewal}

\section{Lindie Koorts}

Historians have a future. We may be averse to forecasting, we become exasperated by the presentism we encounter all around us, and we are critical of narratives that portray the inevitable, forward march of history. But in our own work, we seek to innovate and to break old boundaries - be it through new interpretations, new methodologies, new forms of collaboration, and new means of disseminating our research. We are constantly engaged in renewal and reflection. Anniversaries are moments when we highlight this ongoing pursuit, and Historia's sixtieth anniversary is precisely such a moment. It is not merely a matter of looking back. It is also an opportunity to appreciate the differences and similarities between the past and the present, to take stock of the historical pursuit and to consciously delineate the direction in which we are headed. That is what Historia seeks to do. We need to consider the landscape in which we find ourselves, to understand the direction in which our discipline is headed - and moreover, to chart our path therein. This is expressed in our new cover, which is a visualisation of our endeavour to reflect and renew.

Since its inception in 1956, Historia has gone through several incarnations and phases of renewal - this is inevitably the case with each new editorial team that takes the helm. Over the course of the past year, Historia has undergone several new changes. A new editorial team was appointed, consisting entirely of young, earlycareer historians. This was followed by a new editorial board, with a term-limit of three years, to facilitate future regeneration. The new board represents a wide spread of research expertise, institutions and nationalities. Its members range from established researchers to up-and-coming scholars, and they have challenged us to respond to the demands of our discipline. They have weighed in on the journal landscape in the 21st century, new directions in historical studies and the challenges and opportunities they present. Their advice, some of which is published as contributions in this issue, reflects the particular moment at which we find ourselves: there are questions about the Open Access movement; the need to explore new media platforms beyond the traditional journal format; the need for discussion and debate about our discipline and the wider insight it offers our society; the disintegration of old borders and, especially, the importance of quality research. These are the waters which Historia has to navigate, and we need to do so constructively and innovatively.

\section{How to cite this article:}

L. Koorts, "Editorial. Historia@60: Reflection and Renewal/Van die redaksie. Historia@60: Besinning en vernuwing", Historia 61, 1, May/Mei 2016, pp 1-5.

Copyright: (CThe Author(s). Published under a Creative Commons Attribution Licence. 
Historia's future, and everything else we do, rests on the quality of the research we publish. It calls for editorial vigour and also relies on the contribution made by our peer-reviewers - without their voluntary efforts, the entire system grinds to a halt. Reviewers' reports offer scholars the opportunity to gain new insight into their work and to enhance its quality. In order to facilitate this process, and to give authors the opportunity to receive new and diverse inputs, we have consciously sought to enlarge our reviewer pool, especially by approaching international reviewers. In this issue of Historia, for example, just over half of the anonymous scholars who reviewed our articles are based at universities beyond South Africa's borders. In all this, Historia seeks to be a positive and constructive space, where authors experience the review process as an opportunity to develop their research and the quality of their scholarship. It is also important that their research reaches beyond the pages of our journal, which raises the question of accessibility.

Historia became part of the Open Access movement in 2010, when it joined the SciELO platform under the auspices of the Academy of Science of South Africa (ASSAF). Open Access is crucial to sharing the benefits of scholarly research with the wider society, and we will continue to strive for ease of access. We have decided to add to this by making Historia's back issues, from 1956 to the present, available on our new website (www.hgsa.co.za). It will be tackled as an ongoing project, and it will become an important resource in studying the development of the discipline of History in South Africa, from the second half of the 20th century to the present. It will show Historia's origins, six decades ago, as a journal that was founded to advance an Afrikaner nationalist narrative and its dissemination in universities, schools and museums; and it will reflect its transformation into its present form: a journal that publishes a wide range of scholarly research, from a diverse group of scholars across the Southern African region and beyond.

Historia realises that the scholarly landscape demands constant innovation, especially with the rise of new media platforms. Apart from disseminating quality research, the journal can also play an important role in providing a meeting place for ideas, and as a platform for engaging with history in new ways that go beyond the traditional format. In recent years, scholarly blogging has gained substantial ground internationally - individual scholars, academic departments and even scholarly associations such as the American Historical Association (AHA) have established blogs where scholars publish essays on a range of matters related to their discipline. Blogs provide a forum for the development and spread of ideas and for public engagement. They have also gained ground in South Africa, but there still remains a great deal of room for a consolidated platform where historians of Southern Africa can explore new ways of engaging with our discipline, and where they can weigh in on the questions facing our region. Historians have the ability to be a voice of reason in our heated public debates, and to offer deeper insight into the challenges our society faces. For this reason, Historia is establishing a new blog, which will be edited and curated by its own digital editor, and hosted by the HASA website (www.hgsa.co.za). We extend an open invitation to the history community to 
contribute to our blog, and to turn it into a lively space for interaction. Not only will it publish a wide variety of contributions, but it will also challenge the emerging divide between print journals as exclusive disseminators of research articles, and online platforms as repositories for opinion pieces. Selected contributions from the Historia blog will therefore be published in our print journal as well, thereby building a synergy between digital and print. We are privileged to kick off our blog with a contribution from Bill Nasson which, true to form, showcases an innovative and creative approach to history.

We are excited about the range of possibilities offered by the electronic medium, and plan to build our website into a valuable resource for researchers. Along with our blog and its online Historia archive, our website will host a resources page, with links to online repositories and digitisation projects, which have become a growing trend in recent years. We would welcome your contribution in helping us build this reference hub by sending us links to relevant online resources.

These initiatives are built upon the work of the editorial teams that preceded us, and we are conscious of our responsibility to continue building a strong base for the editors and readers who will succeed us. We shall continue our pursuit of reflection and renewal, and we invite you join us.

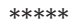

\section{Van die redaksie}

\section{Historia@60: Besinning en vernuwing}

Historici het 'n toekoms. Ons mag dalk 'n hekel aan voorspellings hê, die beheptheid met die hede is dikwels 'n bron van ergernis en ons staan krities teenoor narratiewe wat die onvermydelike opmars van die geskiedenis veronderstel. Tog streef ons in ons eie werk na vernuwing en die aftakeling van ou grense, hetsy deur nuwe vertolkings, metodes, vennootskappe - of geleenthede om die vrug van ons arbeid te versprei. Ons is deurlopend besig om te besin en te vernuwe. Herdenkings is oomblikke waneer ons hierdie strewe belig, en Historia se sestigste herdenking is juis só 'n oomblik. Dit gaan nie net daaroor om terug te kyk nie. Dit is ook 'n geleentheid om na te dink oor die verskille en die ooreenkomste tussen die hede en die verlede, om te besin oor die historiese strewe en om doelbewus die rigting waarin ons beweeg uit te stippel. Dit is waarna Historia streef. Ons moet die landskap waarin ons onsself bevind in oënskou neem, ons moet die rigting waarin ons vakgebied beweeg begryp en ons moet ons weg karteer. Ons nuwe voorblad is 'n uitbeelding van hierdie strewe na besinning en vernuwing.

Sedert sy eerste uitgawe in 1956 het Historia verskeie gedaantewisselings ondergaan - dit is noodwendig die geval met elke nuwe redaksionele span wat die 
stuur oorneem. Historia het die afgelope jaar 'n aantal nuwe veranderinge beleef. 'n Nuwe redaksionele span is aangestel, wat uitsluitlik bestaan uit jong historici wat redelik onlangs tot die veld toegetree het. Daarop het 'n nuwe redaksionele raad gevolg, wat aangestel is vir 'n drie-jaar termyn, ten einde deurlopende hernuwing te verseker. Die nuwe raad verteenwoordig 'n verskeidenheid navorsingsterreine, universiteite en nasionaliteite. Sy lede wissel van gevestigde navorsers tot opkomende jong historici, en hulle het ons reeds begin uitdaag om aan die eise van ons vak te voldoen. Ons is gewys op die aard van die joernaal-landskap in die 21ste eeu, nuwe verwikkelinge in historiese studies en die uitdagings en geleenthede wat dit bied. Van hul raad word in hierdie uitgawe gepubliseer, en dit belig dwingende vraagstukke oor toeganklikheid en die sogenaamde Open Access beweging, die moontlikhede wat deur nuwe media platforms gebied word, die noodsaaklikheid om oor ons vakgebied te debatteer en aan breër samelewingsdebatte deel te neem, die vervaging van ou grense en, bowenal, die belangrikheid van gehalte navorsing. Dit is die waters waarin Historia moet vaar, en ons moet dit op 'n konstruktiewe en vernuwende wyse doen.

Historia se toekoms, en alles wat ons andersins aanpak, berus op die gehalte van die navorsing wat ons publiseer. Dit vereis hoë redaksionele standaarde en dit steun op die bydrae wat ons beoordelaars lewer - sonder hulle vrywillige werk sal die hele stelsel in duie stort. Beoordelaarsverslae bied navorsers die geleentheid om nuwe insette in hul werk te verkry, en om die gehalte daarvan nog verder op te hef. Ten einde hierdie proses te versterk, en ons skrywers van 'n verskeidenheid nuwe insette te voorsien, het ons doelbewustelik ons beoordelaarskorps begin uitbrei, deur veral internasionale beoordelaars te nader. Die artikels in hierdie uitgawe van Historia is gekeur deur 'n groep vakkundiges van wie net so oor die helfte by oorsese universiteite werksaam is. Historia streef bowenal daarna om 'n positiewe en konstruktiewe ruimte te bied, waar outeurs die beoordelingsproses sal beleef as ' $n$ geleentheid om hul navorsing verder te ontwikkel en die gehalte daarvan te verhoog. Dit is ook belangrik dat hul navorsing wyer sal strek as die blaaie van ons joernaal. Dit bring die vraag oor toeganklikheid na vore.

Historia het in 2010, onder die vaandel van die Academy of Science of South Africa (ASSAF) tot die sogenaamde Open Access beweging toegetree toe hy by die SciELO platform aangesluit het. Open Access is van kritieke belang om die vrug van akademiese navorsing met die breër samelewing te deel, en ons sal aanhou om onsself vir toeganklikheid te beywer. Ons het besluit om verder daartoe by te dra deur vorige uitgawes van Historia, vanaf sy eerste verskyning in 1956 tot die hede, op ons webwerf (www.hgsa.co.za) beskikbaar te maak. Dit sal as 'n deurlopende projek aangepak word, en dit sal 'n belangrike hulpbron wees vir diegene wat die ontwikkeling van historiese studies in Suid-Afrika, vanaf die tweede helfte van die twintigste eeu tot die hede, wil bestudeer. Daarin sal Historia se oorsprong te siene wees, as 'n joernaal wat gestig is om 'n Afrikaner nasionalistiese narratief te bevorder en dit in universiteite, skole en museums te verkondig; en dit sal ook wys hoe die joernaal omvorm is tot sy huidige gedaante: 'n joernaal wat 'n wye verskeidenheid 
akademiese navorsing, van 'n uiteenlopende groep historici, van dwarsoor die suiderAfrikaanse streek en nog verder, publiseer.

Historia besef die vakkundige landskap vereis deurlopende vernuwing, veral gegewe die opkoms van nuwe media platforms. Buiten vir die publikasie van gehalte navorsing kan die joernaal ook 'n belangrike rol speel as 'n bymekaarkomplek vir die uitruil van idees, en as 'n platform waar daar op nuwe wyses, en in nuwe formate, met geskiedenis omgegaan kan word. 'n Belangrike internasionale beweging van die afgelope jare is die opkoms van akademiese bloggers - individuele historici, geskiedenis departemente en selfs akademiese genootskappe soos die American Historical Association (AHA) het die afgelope klompie jare blogs gestig waar historici hul mening oor 'n verskeidenheid sake kan lug. Blogs verskaf 'n forum vir die ontwikkeling en verspreiding van idees, en verskaf aan historici die geleentheid om tot 'n wyer gehoor, buite die ivoortoring, te spreek. Dit het ook reeds in Suid-Afrika opgang begin maak, maar daar is steeds heelwat ruimte vir 'n gekonsolideerde platform waar suider-Afrikaanse historici die nuwe moontlikhede van ons vakgebied kan verken, en waar hulle hul stemme kan verhef oor die vraagstukke waarmee ons streek worstel. Historici het die vermoë om 'n redelike en geberedeneerde stem binne ons vurige openbare debatte te wees, en hulle kan dieper insigte bied op die uitdagings waarmee ons samelewing te kampe het. Om hierdie rede het Historia besluit om 'n nuwe blog te stig, met 'n digitale redakteur, wat op die HGSA se webwerf (www.hgsa.co.za) gehuisves sal word. Ons wil graag 'n ope uitnodiging aan die historiese gemeenskap rig om tot ons blog by te dra, en dit 'n lewendige bymekaarkomplek te maak. Die blog sal 'n wye verskeidenheid bydraes publiseer, en hy sal ook 'n uitdaging bied aan die toenemde skeiding tussen gedrukte joernale wat navorsingsartikels versprei, en internet-platforms wat meningstukke huisves. 'n Keur van bydraes uit die Historia blog sal daarom ook in die gedrukte joernaal verskyn, om sodoende 'n sinergie tussen die gedrukte en digitale formaat te bewerkstellig. Dit is ons voorreg om af te skop met 'n blog-bydrae deur Bill Nasson wat, trou aan sy aard, vir ons wys hoe om die geskiedenis op 'n vernuwende en kreatiewe wyse aan te pak.

Ons is opgewonde oor die verskeie moontlikhede wat die elektroniese medium ons bied, en ons wil dit inspan om ons webwerf uit te bou tot ' $n$ waardevolle hulpbron vir navorsers. Tesame met ons blog en ons aanlyn Historia argief, sal ons webwerf ook 'n hulpbronne blad huisves, met skakels na aanlyn argiewe en nuwe digitaliseringsprojekte, wat een van die vername tendense van die afgelope jare geword het. Ons sal dit verwelkom indien u tot die bou van so 'n verwysingspilpunt wil bydra deur vir ons skakels na relevante aanlyn hulpbronne te stuur.

Al hierdie inisiatiewe berus op die arbeid van die redaksionele spanne wat ons voorafgegaan het, en ons is deeglik bewus van ons verantwoordelikeid om aan te hou bou aan 'n sterk basis vir die redakteurs en lesers wat na ons gaan kom. Ons sal volhard in ons strewe na besinning en vernuwing, en ons nooi u uit om by ons aan te sluit. 